УДК 37.015.31:316.42-053.5

DOI:

Олена Квас, доктор педагогічних наук, професор кафедри загальної та соиіальної педагогіки Львівського національного університету імені Івана Франка

\title{
ДИТИНОЦЕНТРИЧНІ ПОГЛЯДИ ТА ІДЕЇ У ПЕДАГОГІЧНІЙ СПАДЩИНІ АВГУСТИНА ВОЛОШИНА
}

Стаття присвячена розгляду засад дитиночентризму як педагогічного світогляду щодо виховання дитини в науковій та практичній діяльності відомого педагога, культурно-освітнього, релігійного $і$ державного діяча, просвітителя, журналіста й письменника, визначного гуманіста Закарпатського краю на зламі XIX - ХХ століть, професора Августина Волошина (1874-1945р.). У изентрі педагогічної концепціі А. Волошина і головним об'єктом виховання є дитина на всіх етапах ї̈ розвитку, з усіма властивими їи вродженими задатками, здібностями, талантами.

Ключові слова: Августин Волочин; педагогічна спадщина; дитиноцентризм; виховання; розвиток.

Jim. 7.

Olena Kvas, Doctor of Sciences (Pedagogy), Professor of the General and Social Pedagogy Department Lviv Ivan Franko National University

\section{THE CHILD'S CENTRIC VIEWS AND IDEAS IN THE PEDAGOGICAL HERITAGE OF AVHUSTYN VOLOSHYN}

The article is devoted to the study of principles of child-centeredness as a pedagogical outlook on the upbringing of the child in the scientific and practical activities of the well-known pedagogue, cultural and educational, religious and state figure, educator, journalist and writer, outstanding humanist of the Transcarpathian region at the turn of the 19th and 20th centuries, professor Avhustyn Voloshyn (1874 - 1945).

The study of the scientific and pedagogical and journalistic works of the outstanding teacher makes it possible to conclude that the dialectics of the education and development of the child's personality are regarded by them as interdependent phenomena: development affects education, and education determines development. Due to purposeful education, on the conviction of the teacher, a person is formed; conditions are not only made for the development of inherited natural instincts of the child and the physical characteristics, but also for acquisition of new features and qualities.

Avhustyn Voloshyn engaged himself actively in the pedagogical education of parents and initiated its dissemination among the general population of the Transcarpathian region. Through active ways of teaching pedagogical knowledge the parents of pupils from the school side, he considered the organization of thematic lectures and parent conferences, involving parents into the organization of joint holidays which would help them to get to know the child more deeply.

In the center of the pedagogical concept of A. Voloshyn and the main object of education is a child at all stages of development, with all inherent in the innate instincts, abilities, and talents. In this case, the main task of education, according to the teacher, is to ensure the development of these qualities, the formation of a nationally conscious, humane, mature, creative and hard-working personality capable for conscious social choice and enrichment of the intellectual, spiritual and cultural potential of their people.

Keywords: Avhustyn Voloshyn; pedagogical heritage; childhood centric; an education; development.

П остановка проблеми. У другій половині XIX та в першій половині XX ст. дитиноцентризм стає одним із найбільш важливих постулатів для більшості тогочасних педагогічних напрямів. Він увійшов в історію виховання як педагогічна течія або своєрідний світогляд щодо виховання дитини. Для сучасної педагогічної науки поняття дитиноцентризму не обмежується тільки загальновідомою констатацією того, що це - один з напрямів у педагогіці, який виник у XIX ст. Дитиноцентризм чи педагогіка дитинства присутня на полях будь- якої з карт, які класифікують сучасні педагогічні напрямки та течії, незалежно від їхніх філософських та суспільно-політичних ідеологем.

Не викликає сумніву і те, що дитиноцентризм сприяє цілісному трактуванню педагогіки в історичній перспективі, через те, що зі зміною поколінь певною мірою змінюється й педагогіка. У зв' язку із цим особливої уваги заслуговує аналіз праць і життєвого шляху педагогів, учених, громадських діячів, які зробили вагомий внесок у розвиток дитиноцентричних ідей. Фундаментальне вивчення їхніх педагогічних 
поглядів, об'єктивна оцінка, глибоке й всебічне осмислення їхньої науково-педагогічної діяльності допомагає оптимально поєднати класичну спадщину минулого із сучасними досягненнями наукової думки. Серед таких педагогів важливе місце посідає Августин Волошин - визначний вчений, громадський, культурний й церковний діяч Закарпаття, президент Карпатської України.

Мета статті - окреслити засади дитиноцентричного світогляду Августина Волошина на зламі XIX та XX століть.

Аналіз останніх досліджень і публікацій. До джерел педагогічної спадщини вченого Августина Волошина зверталось чимало науковців: Т. Беднаржова, С. Бобела, 3. Ваколя, М. Вегеш, Н. Вигодованець, М. Свтух, В. Кемінь, М. Кляп, І. Розман, В. Туряниця, Г. Шикітка та ін.

Різні аспекти публіцистичної, мовознавчої, літературознавчої, громадсько-політичної діяльності Августина Волошина знайшли своє втілення у працях таких вітчизняних науковців як В. Ганчин, В. Гренджа-Донський, Н. Грибенюк, М. Делеган, О. Довганич, В. Задорожний, М. Зимомря, А. Зінченко, Д. Кадар, Ф. Куля, А. Кущинський, В. Лар, Л. Маляр, О. Мишанич, В. Німчук, Л.Ньорба, І. Петров, В. Попик, Н. Ребрик, Т. Сабадош, М. Сабова, І. Сенько, В. Тарасюк, М. Тисянський, М. Фостун, В. Худанич, І.Чаварга, П. Чучка, В. Шандор, А. Штефан, А. Якеш, М. Яшко та ін.

Розвідки згаданих учених певною мірою збагатили наукову та історіографічну базу. У центрі уваги дослідників педагогічної спадщини А. Волошина були різні питання процесів навчання і виховання підростаючого покоління. Однак дослідження саме дитиноцентричних поглядів та ідей вченого потребують подальшого вивчення та висвітлення.

Виклад основного матеріалу. Августин Волошин утвердив себе як високоосвічена інтелігентна людина, талановитий педагог європейського рівня, культурно-освітній, релігійний і державний діяч, просвітитель, журналіст і письменник, професор і ректор Українського Вільного Університету в Празі, член чехословацького парламенту, прем'єр-міністр та Президент Карпатської України, який палко любив свою батьківщину і бажав рідному українському народові посісти "почесне місце в родині цивілізованих націй” [1,5-7].

Народився Августин Волошин 17 березня 1874 р. в сім'ї сільського священика у маленькому гірському селі Келечин Волівського округу (нині це Міжгірський район). Як відзначає відомий науковець, дослідник життя і творчості Августина
Волошина О. Мишанич: “...Рід Волошинів походив із лібертинів (вільних селян) села Великі Лучки біля Мукачева. Дід Августина Іван був священиком у Великих Лучках, батько у 1867 р. призначений священиком у с. Келечин Марамороської жупи. Мати Августина Волошина Емілія Зомборі теж походила із родини священика. ...Незважаючи на те, що у 70-х рр. майже всі священичі родини на Закарпатті були “змадяризовані”, у родині Волошинів свідомо трималися руської мови і звичаїв, розмовною мовою у сім’ї була місцева руська (українська) мова" $[3,6] .3$ дитячих років А. Волошин виховувався в дусі християнської моралі, батьки прищеплювали синові любов до рідної мови, до українського народу, його звичаїв і традицій. Саме 3 рідного дому, на переконання дослідників, Августин Волошин виніс знання говірки рідного села, якою потім послуговувався у своїй науковопрактичній роботі $[3,6]$.

Біографи Августина Волошина наголошують на особливому впливу батьківської сім'ї на формування його національної свідомості.

У 1883 р. він був прийнятий до першого класу Ужгородської гімназії, яку закінчив у 1892 році. Августин Волошин у 1893 році вступив до теологічного ліцею м. Ужгорода, який закінчив у 1896 р. Цього ж року він одружився з Іриною Петрик - донькою професора Ужгородської гімназії, родича видатного карпатоукраїнського громадського та культурного діяча XIX ст. о. Олександра Духновича, в особі якої отримав не тільки люблячу дружину, але й надійного помічника й соратника. Відзначимо, що А. Волошин блискуче оволодів іноземними мовами: грецькою, латинською, німецькою, чеською, словацькою, сербською, російською та староболгарською.

У 1897 році А. Волошин був висвячений на священика i почав служити капеланом Ужгородської Цегольнянської Преображенської церкви. Це був складний час для грекокатолицької церкви в Закарпатті, яка вела активну боротьбу за кирилицю. Не стояв осторонь у цьому процесі і молодий священик А. Волошин. I хоча на той час він готувався до релігійної діяльності, але не мислив себе діячем лише церковного життя. Саме тому вже у 1899 - 1900 рр. закінчує Вищу педагогічну школу в Будапешті, отримує диплом викладача математики i фізики горожанських шкіл та розпочинає педагогічну діяльність в Ужгородській учительській семінарії, де працює до 1917 року на посаді професора, а з 1917 до жовтня 1938 рр. - директором. У період 1906 - 1934 рр. він поєднує свою педагогічну 
діяльність в учительській семінарії з роботою в Ужгородській духовній семінарії, де обіймає посаду професора педагогіки [7, 23].

На формування світогляду, педагогічних поглядів Августина Волошина вплинуло налагодження ним зв'язків з науковцями та громадсько-культурними діячами Словаччини, Чехії, Угорщини та Галичини.

Підвалинами майбутнього, однією з головних рушійних сил суспільного розвитку Августин Волошин вважав культуру, яку розглядав як єдність національного й соціально-політичного життя, що живиться народними традиціями. Кожен народ має свою вроджену культурну спадщину, свій народний геній, свою індивідуальність і лиш на основі цієї індивідуальності може творити культуру й причинитися до вселюдської культури, наголошував А. Волошин, звертаючись до делегатів з'їзду молоді краю в липні 1929 р. [3, $118]$.

А. Волошин разом 3 іншими культурноосвітніми діячами вів активний пошук шляхів розвитку української системи освіти, якій відводив центральне місце усправі піднесення життя краян, їх національної свідомості. Основне завдання освіти, на його думку, полягає у служінні інтересам народу, його культурі, на потреби гармонійного розвитку дитини. Так, зокрема, у статті “Наша задача" (1925 р.) він зазначає: “...воскресінн народа нашого на всіх полях народного життя має відбуватися саме через “діло виховання”, реформування школи” [4, 1-2].

За ініціативи А. Волошина стрімко розширюється мережа шкіл, викладання у яких велося рідною для учнів мовою. Якщо у 1920 році в Закарпатті функціонувало 475 народних шкіл, 3 яких 21 була 3 українською мовою навчання, то вже у 1932 - 1934 рр. налічувалося 532 школи, 3 яких 373 школи були українськими. Крім того діяли 14 українських горожанських шкіл, 4 гімназії (3 них одна угорська), 3 учительські семінарії, 2 українські торговельні школи.

А. Волошин добре усвідомлював, що поширення в народі освіти і культури неможливе без участі вчителя. Будучи директором учительської семінарії відбір семінаристів на навчання він проводив не лише з дітей заможних сімей, а насамперед дітей робітників, ремісників та селян, які хотіли здобувати освіту, тому що був переконаний в тому, що саме ці люди будуть ближче до народу, а своєю благородною працею слугуватимуть прикладом для простої людини. Він виховав сотні учнів, які ширили освіту на Закарпатті, проводили велику культурну, просвітницьку і громадсько-політичну роботу серед народу.

3-під пера видатного педагога після “Методической граматики руського языка для народних школ" (1899 р.) та "Читанки для угрорусской молодежи, часть I, II” (1900р.) виходять ще 40 підручників рідною мовою для учнів школи та вчителів: “Азбука” (1904р.), “Азбука і перва читанка для I кл. народних школ на русскомъязыці” (1905 р., 1913 р.), “Малая библия для низших кл. народних школь” (1904р.),. “Наука о числахъ для 1 і 2 кл. нар. школь” (1919 р.), “Наука о числахъ для 3 кл. народныхъ школь" (1919 р.), “Наука о числахъ для IV кл. народныхъ школь” (1919р.), “Физика” (1923р.), “Наука стилізацій” (1920р.), “О письменно мязыци Подкарпатських русинов” (1920р.), “Педагогика и дидактика для учительних семинарій” (1923 р.), "Исторія педагогики для учительних семинарій" (1923 р.), “О соціальнім вихованю” (1924 р.), “Мала читанка для II и III кл. народних школ" (1930р.), “Коротка історія педагогіки для учительських семінарій” (1931р.), “Педагогична психологія" (1932р.), “Загальна педагогіка" (1932 р.) “Дидактика (1933р.)”, “Методика народно-шкільного навчання” (1935 р.), “Логіка" (1935 р.), “Коротка історія психології’ (1937 р.) та ін.

Щоб дійти до рівня культури сусідніх країн і більш якісної підготовки вчителів, які б понесли освіту в як найширші верстви населення, він пропонує відкрити педагогічну академію, яка б у майбутньому стала основою для відкриття “подкарпатско-руського університету” [5, 82].

Августина Волошина як педагога неможливо розглядати поза його літературною діяльністю. Літературні твори А. Волошина, написані доступною і зрозумілою простому народу мовою, які відзначалися яскраво вираженим людиноцентованим характером. До найкращих художніх творів і популярних книжечок Августина Волошина належать "Робінзон”, “Сорок казок”, “Іцко-Яцко”, “Празники”, “Наш страшний ворог”, “Разговор о векселях”, “Фабіола”, драма “Марійка-Верховинка” і драма на моральну тематику “Без Бога ні до порога". Саме літературний твір у педагогічній концепції А. Волошина постає своєрідною формою обгрунтування можливостей урізноманітнення шляхів просвітницької діяльності серед народу, дієвим джерелом впливу на розвиток його духовно-моральних якостей, національної свідомості та розвитку дитиноцентричних ідей.

Особлива мова про Августина Волошина як про людину-благодійника, який з великою теплотою й увагою ставився до сиріт, бідних $\mathrm{i}$ 
знедолених. Досить показовим у цьому плані можна вважати той факт, що у 1932 р. разом із дружиною Іриною А. Волошин подарував під сиротинець "Нова родина" свій двоповерховий будинок в м. Ужгороді (нині це вул. А. Волошина, № 36), де виховувалось 22 дітей-сиріт. Саме ж подружжя переселилося в маленьку хатинку у дворі. Подружжя Волошиних узяло на себе всі турботи з матеріального забезпечення і духовного виховання сиріт.

3 метою підготовки дітей до майбутнього самостійного життя і фінансового забезпечення у сиротинці була передбачена робота, спрямована на освоєння ними однієї з вибраних професій: кухаря, швачки, прачки, кондитера або ж перукаря. Ті ж, хто добре вчився, продовжували навчання у жіночій учительській семінарії, торговельній чи музичній школах. Вартість навчання за них оплачував о. А. Волошин. У сиротинці діти вчилися і музичної грамоти - грати на скрипці, домбрі, гітарі, піаніно; вокального і хорового співу та народних танців.

Свідченням особливої родинної атмосфери у сиротинці, неперевершеної турботи і любові Августина Волошина і його дружини до дітейсиріт, яких вони сприймали як рідних, можна вважати те, що самого А. Волошина вихованці сиротинця називали татом, а його дружину мамою.

У 1936 році несподівано померла пані Ірина головний вихователь, і діти немов вдруге осиротіли. Після окупації Карпатської України Угорщиною сиротинець переселився до м. Хуста.

Прикладом особливої турботи А. Волошина про дітей-сиріт слід вважати і його “Заповіт (Тестамент)”, складений 19 серпня 1944 р. у Празі, в якому він заповідає: "Мій маєток в селі Селешка (окр. Крал. Хлумец) віддаю Чину с. Василіянок в Ужгороді для піддержування сиротинців, заложених пок. жінкою моєю і мною в Ужгороді і в Хусті” [3, 497]. 19 липня 1945 року, внаслідок тяжких тортур в бутирській в'язниці, серце видатного педагога зупинилося.

Вивчення науково-педагогічних та публіцистичних праць видатного педагога дозволяє дійти висновку, що діалектика виховання та розвитку особистості дитини розглядаються ним як явища взаємозалежні: розвиток впливає на виховання, а виховання визначає розвиток. Завдяки цілеспрямованому вихованню, на переконання педагога, формується особистість, створюються умови для розвитку не тільки успадкованих природних задатків дитини та її фізичних особливостей, але й набуття нею нових рис i якостей. У праці “Педагогіка и дидактика для учительських семінарій” (1923) А. Волошин відзначав: “Дитина не $\epsilon$ такою матерією, як воск, iз котрого можна виліпити, яку хочеме форму, но не являєтся такою лічностію, котра на світ Божий принесла 3 собою вже готову свою індивідуальності”' $[6,13]$. Продуктивною стає ідея Августина Волошина про нерозривний зв'язок $і$ взаємообумовленість усіх напрямів розвитку особистості дитини в родинному колі - анатомобіологічному, психічному, соціальному та їх орієнтації на виховний ідеал на основі християнської моральності, формування активної, зрілої особистості.

У праці “Загальна педагогіка” (1932) в розділі 6 “Доби виховання” Августин Волошин окреслює специфіку кожного вікового періоду розвитку дитини та дає поради стосовно їх урахування у процесі виховання дитини [2]. Так, головна мета виховання дитини у ранній період - “опередити хиби і шкоди, котрі могли би виходити із необдуманности недолітка" $[2,13]$. При цьому педагог звертає увагу батьків на важливість урахування природовідповідного розвитку дитини та прищеплення ій самостійності, щоби “доглядом не гальмувати вільне ділання недолітка”, і лише тоді втручатися в справи недолітка, коли вчинок його буде шкідливим $[2,14]$.

Як педагог-практик, культурно-освітянський діяч, літератор, священнослужитель, Августин Волошин сам активно займався педагогічною просвітою батьків і виступав ініціатором її поширення серед широких верств населення Закарпатського краю. Дієвими шляхами озброєння педагогічними знаннями батьків учнівської молоді з боку школи він вважав організацію тематичних лекторіїв і батьківських конференцій, залучення батьків до проведення спільних свят, участь у яких допомагала їм глибше пізнати дитину.

Аналіз педагогічних праць Августина Волошина дозволяє стверджувати, що дитиноцентричні ідеї виховання висвітлюється насамперед у таких його роботах, як "Педагогіка і дидактика”, Загальна педагогіка”, “Дидактика”, “О соціальном вихованню”, “Методика”, “Коротка історія педагогіки”, “Методика народношкільного навчання”, “Народна педагогія” тощо, де прямо або опосередковано наголошується на важливості володіння педагогічними та психологічними знаннями та окреслюється зміст та шляхи просвітницької роботи 3 метою удосконалення процесу виховання на основі принципів народності, природовідповідності та культуровідповідності, раціоналізму та гуманізму.

Висновок. У центрі педагогічної концепції 
А.Волошина і головним об'єктом виховання перебуває дитина на всіх етапах іiї розвитку, з усіма властивими їй вродженими задатками, здібностями, талантами. При цьому головним завданням виховання, на переконання педагога, $\epsilon$ забезпечення розвитку цих якостей, формування національно свідомої, гуманної, зрілої, творчої і працелюбної особистості, здатної до свідомого суспільного вибору й збагачення інтелектуального, духовного й культурного потенціалу свого народу. Разом із тим об'єктом виховання у педагогічній концепції А. Волошина, окрім дитини, учня, виступає і доросле населення, насамперед батьки учнівської молоді, які, на його переконання, тільки будучи прикладом для своїх дітей, здатні забезпечити їх повноцінний всебічний розвиток.

\section{ЛІТЕРАТУРА}

1. Беднаржова Т. Августин Волошин державний діяч, педагог, мислитель: монографія / Тетяна Беднаржова. - Львів.: “Основа”. Львівська Богословська Академія, 1995. - 240 с.

2. Волошин А. Загальна педагогіка / Августин Волошин. - Ужгород: Накладом педагогічного товариства Підкарпатської Руси, 1932. - 25 с.

3. Волошин А. Вибрані твори / Упорядкування, вступна стаття та примітки О. В. Мишанича. Ужгород: ВАТ “Видавництво “Закарпаття”, 2002. $-528 \mathrm{c}$.

4. Волошин А. Наша задача / Августин Волошин // Подкарпатска Русь. - 1925. - Рфчник II. - Ч. 1. - C. 1-2.

5. Волошин А. Педагогічна академія / А. Волошин // Учитель. - Ужгород, 1921. Рочникъ II. - № 6. - С. 81 - 83 .

6. Волошин А. Педагогика и дидактика для учительських семинарий / Августин Волошин. Ужгород: “Уніо", 1923 - 186 с.

7. Зимомря М. Августин Волошин / М. Зимомря, В. Гомоннай, М. Вегеш. - Ужгород, 1995. $-101 \mathrm{c}$.

\section{REFERENCES}

1. Bednarzhova, T. (1995). Avhustyn Voloshyn - derzhavnyi diiach, pedahoh, myslytel: monohrafiia [Avhustyn Voloshyn is a statesman, a teacher, a thinker: a monograph]. Lviv: "Osnova". Lvivska Bohoslovska Akademiia, 240 p. [in Ukrainian].

2. Voloshyn, A. (1932). Zahalna pedahohika [General Pedagogy]. Uzhhorod: Nakladom pedahohichnoho tovarystva Pidkarpatskoi Rusy, 25 p. [in Ukrainian].

3. Voloshyn, A. (2002). Vybrani tvory [Selected Works]. Uporiadkuvannia, vstupna stattia ta prymitky O. V. Myshanycha [Ordering, introductory article and notes by O. V. Myshanych]. Uzhhorod: VAT "Vydavnytstvo "Zakarpattia", 528 p. [in Ukrainian].

4. Voloshyn, A. (1925). Nasha zadacha [Our task]. Podkarpatska Rus. Rochnyk II. Part1, pp. 12. [in Ukrainian].

5. Voloshyn, A. (1921). Pedahohichna akademiia [Pedagogical Academy]. Uchytel. Uzhhorod, Rochnykъ II. No. 6, pp. 81 - 83. [in Ukrainian].

6. Voloshin, A. (1923). Pedagogika i didaktika dlya uchitelskikh seminariy [Pedagogy and Didactics for teachers' seminars]. Uzhgorod: "Unio", 186 p. [in Russian].

7. Zymomria, M., Homonnai, V. \& Vehesh, M. (1995). Avhustyn Voloshyn [Avhustyn Voloshyn]. Uzhhorod, 101 p. [in Ukrainian].

Стаття надійшла до редакції 04.06.2018

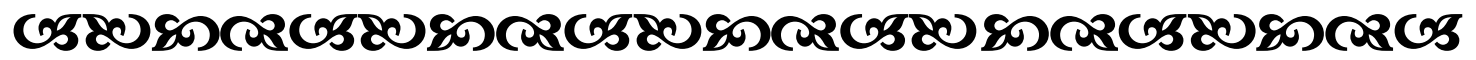

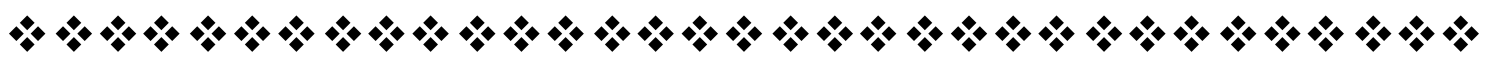

...один із секретів педагогічної творчості й полягає в тому, щоб пробудити в учителя інтерес до пошуку, до аналізу власної роботи. Хто намагається розібратися в хорошому й поганому на своїх уроқах у своїх взаєминах з вихованиями, той уже досяг половини успіху.

Василь Сухомлинський украйнсъкий педагог

"Dитинство часто тримає в своїхслабких пальиях істину, яқу не можуть утримати дорослі люди своїми мужніми руками і відқриття якої становить гордість пізнішихроків".

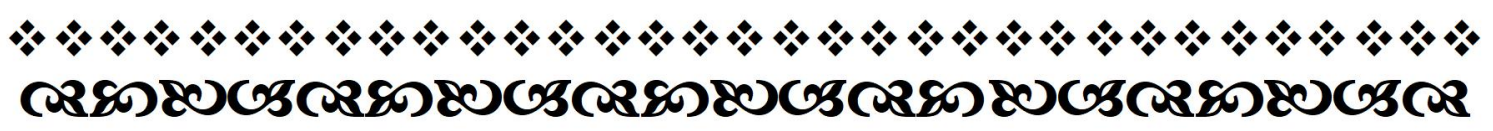

Молодь і ринок №7 (162), 2018 